\title{
PNOC wt Allele
}

National Cancer Institute

\section{Source}

National Cancer Institute. PNOC wt Allele. NCI Thesaurus. Code C118220.

Human PNOC wild-type allele is located in the vicinity of 8p21 and is approximately $26 \mathrm{~kb}$ in length. This allele, which encodes prepronociceptin protein, is involved in the regulation of the perception of pain. 